\title{
Extracorporeal Membrane Oxygenation
}

Editors

NITIN PURI

MICHAEL BARAM

NICHOLAS C. CAVAROCCHI

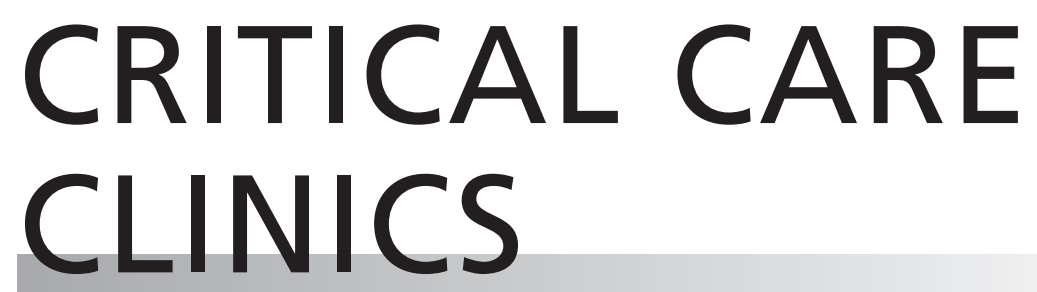

www.criticalcare.theclinics.com

Consulting Editor

JOHN A. KELLUM

October 2017 • Volume 33 • Number 4 